$\xi=-1$

\title{
Measuring the Financial Performance of Enterprises Under Ministry of Energy and Mineral Resources (EMR) an Indonesia Experience
}

\author{
Wiwiek Mardawiyah Daryanto ${ }^{1}$, Sudarmawan Samidi ${ }^{2}$ \\ ${ }^{1}$ Sekolah Tinggi Manajemen Ipmi, Jakarta 12750, Indonesia \\ ${ }^{2}$ Faculty of Economics, Universitas Krisnadwipayana, Jakarta 13077, Indonesia \\ *Corresponding author E-mail: wiwiek.daryanto@ipmi.ac.id
}

\begin{abstract}
The assessment of financial performance is becoming increasingly important. The Decree No. KEP-100/MBU/2002 issued by Ministry of Stated Owned Enterprises of Indonesia on June 2002 provide the mandatory measuring and rating the financial health condition for all subsidiaries of SOEs. The circumstance is of relevance in the Indonesian context, characterized by a strong corporate governance but the lack of transparency. This study aims to measure the level of financial performance by investigating return on equity, return on investment, cash ratio, current ratio, collection period, inventory turnover, total asset turnover and total equity to total asset ratio. Then, to compare the company's financial performance between coal mining and natural gas industry. The data were collected from two stated owned enterprises under Ministry of Energy and Mineral Resources (EMR) for the period 2011 - 2015. The result shows that the industry has a good financial health condition which achieved level AAA and AA. Furthermore, this industry has a challenge in inventory management and assets utilization. Therefore, this study can be useful for the manager to tackle the challenge and improve its efficiency.
\end{abstract}

Keywords: EMR; financial performance; SOEs; inventory management; asset utilization.

\section{Introduction}

Coal mining and natural gas industry is an important pillar of economic development in Indonesia. This industry has been a major contributor to the state income treasury. Currently, Indonesia as the fifth large of coal producers and exporter in the world and the third large reserves in the Asia Pacific region (after Australia and the People's Republic of China), contributing to $1.5 \%$ of total world gas reserves (1). In natural gas industry, Indonesia as the tenth large producers of natural gas in the world and the second largest producers in Asia Pacific region after the People's Republic of China (2). Natural gas contributed about $23 \%$ of the primary energy sources of the world.

In Indonesia, Coal is used for household purposes (cooking) and a wide range of industries such as steel and cement, while natural gas is mostly used for fuel stove and fuel vehicles. It has played a significant role in most sectors such as industrial, power generation, commercial and residence. Furthermore, there are a lot of natural gas reserves in the world - which can be developed and produced without the need for huge investments - natural gas is likely to become increasingly important in the future because most countries want to reduce dependence on energy sources which are expensive and unfriendly environments such as oil.

However, this coal mining sector is experiencing a downward trend since the beginning of 2011. The commodity prices of mineral and coal experienced degeneration and have not shown good signs. Indonesia as a rich country in mining commodities also feel the effects. The other worse thing, they cannot determine the price of the mining commodity itself. The prices of all these commodi- ties are determined by the market so commodity prices are highly vulnerable to supply and demand dynamics of the world. Moreover, the economic climate, the economic embargo, foreign policy, and the price of other energy commodities such as oil also can help influence market pricing.

The problem also arises from the natural gas industry where some of the raw materials should be imported (3). Therefore, the procurement process is often controlled by an exporter of raw materials abroad which is also the manufacturer of the same goods with goods produced in the country. This has become a serious threat to the domestic industry due to import surge occurs, among other production industries Casing Tubing, Pipe Ducts, and so forth.

The government gives mandatory to the company under the Ministry of Stated Owned Enterprises of Indonesia that they should implement financial ratio analysis to measure the level of financial health. The previous research about financial performance has been discussed in many sectors such as a hospital, bank, and small business. (4) stated that financial ratio is useful to measure the performance of a small business and it can be used to predict the failure. (5) used a financial ratio to examine the financial performance of America power/energy industry and to compare other major industrial nations including Japan and the European nations. The finding shows that debt and profitability ratios are important indicators to analyze their financial performance and American power companies have less managerial and financial skills than Japanese companies.

However, the literature about financial performance in coal mining and natural gas industry is very limited. Therefore, the purpose of this study is to measure the financial performance of coal mining and natural gas industry which validated by the decree of Ministry of State Owned Enterprises (SEOs) No. KEP-100/MBU/2002 
and to compare the financial performance between PT. Bukit Asam and PT. Perusahaan Gas Negara.

In view of this, the research questions are 1) what is the financial performance of coal mining and natural gas industry based on the decree of Ministry of State Owned Enterprises (SEOs) No. KEP100/MBU/2002? 2) What is the difference of financial performance between PT. Bukit Asam and PT. Perusahaan Gas Negara? This study is beneficial for academician because it extends the knowledge of financial ratio in the real practice. In addition, it helps student and lecturer to understand financial ratio more effectively. This study is also important for the manager which can help them to analyze the company's situation and guide them before making the decision.

\section{Literature Review}

\subsection{Coal Mining Industry in Indonesia}

Indonesia is one of the largest coal producers and the leading exporter of thermal coal in the world. The coal production in Indonesia exceeded the production in Australia since 2005 (6). In relation with the global coal reserves, Indonesia is now ranked 10th with about 3.1 percent of total global coal reserves are proven by the BP Statistical Review of World Energy. According to (7), Indonesia's coal reserves expected to be exhausted in about 83 years if the current production rate is passed. Based on the study conducted by (8) stated that the significant portion of export thermal coal consists of the medium quality type (between 5100 and 6100 cal/gram) and the low quality (below $5100 \mathrm{cal} /$ gram) which is largely demand from China and India. In addition, (9) added that about 60 percent of Indonesia's total coal reserves consist of lowquality coal that is cheaper (sub-bituminous) which contains less than $6100 \mathrm{cal} / \mathrm{gram}$.

Based on the Table 1, coal production has increased from 217 million $\mathrm{m} 2$ in 2007 to 461 million $\mathrm{m} 2$ in 2015 , while the amount of export increased from 163 million $\mathrm{m} 2$ in 2007 to 402 million $\mathrm{m} 2$ in 2013 and then it decreased to 366 million $\mathrm{m} 2$ in 2015 . The amount of coal consumption in Indonesia decreased from 61 million tons in 2007 to 49 million tons in 2008, and then it increased to 87 million tons in 2015 . The price of this commodity decreased from $\$ 70.7$ in 2009 to $\$ 60.1$ in 2015 .

Table 1: Overview of Production, Export, Consumption, and Price.

\begin{tabular}{|c|c|c|c|c|c|c|c|c|c|}
\hline & 2007 & 2008 & 2009 & 2010 & 2011 & 2012 & 2013 & 2014 & 2015 \\
\hline $\begin{array}{c}\text { Production (in } \\
\text { million m2) }\end{array}$ & 217 & 240 & 254 & 275 & 353 & 412 & 474 & 458 & 461 \\
\hline $\begin{array}{c}\text { Export (in million } \\
\text { tons) }\end{array}$ & 163 & 191 & 198 & 210 & 287 & 345 & 402 & 382 & 366 \\
\hline $\begin{array}{c}\text { Domestic (in } \\
\text { million tons) }\end{array}$ & 61 & 49 & 56 & 65 & 66 & 67 & 72 & 76 & 87 \\
\hline $\begin{array}{c}\text { Price(HBA) (in } \\
\text { USD/ton) }\end{array}$ & n.a. & n.a. & 70.7 & 91.7 & 118.4 & 95.5 & 82.9 & 72.6 & 60.1 \\
\hline
\end{tabular}

Source: Indonesia-Investments (2015).

In this industry, PT. Bukit Asam (Persero) Tbk is the only StateOwned Companies which has an extensive experience from end to end business. It was established on March 02, 1981. The business activities of this company are front to end business of coal production which start from general surveying of coal, exploration, exploitation, processing, refining, transportation and trading, maintenance for internal and external port facilities, operation of steam power plants for internal and external needs and providing consulting services related to the coal mining industry as well as its derivative products.

\subsection{Natural Gas Industry in Indonesia}

Indonesia produces natural gas about twice as much of it consumes. Nevertheless, this does not mean that domestic gas production can meet the demand of domestic gas. In fact, there is a shortage of gas for domestic industries in Indonesia. Perusahaan Gas Negara (PGN) has not been able to meet domestic demand. It has impacts that have broad coverage because it caused the State Electricity Company (PLN), gas consumers the largest domestic, experienced a structural shortage of supply of gas and forcing PLN to switch the materials of fossil fuels - which are more expensive and not environmentally friendly - to other materials, such as oil, to produce electricity. Nevertheless, power outages are common across the country (especially outside the big cities of Java), and hence weighing on the country's industries. Moreover, nearly 80 million people in Indonesia do not have access to electricity as indicated by the percentage of electricity Indonesia is relatively low at $84.1 \%$ in 2014 (10).

The Indonesian government aims to limit the country's gas exports to secure domestic supply while encouraging the use of natural gas as a fuel source for industrial and personal consumption. Most of the country's gas production is dominated by foreign companies such as CNOOC Limited, Total E \& P Indonesia, Conoco Philips, BP Tangguh, and Exxon Mobil Oil Indonesia, contributing to about $87 \%$ of natural gas production in Indonesia. The remaining $13 \%$ is produced by State-Owned Enterprises (SOEs) PT. Pertamina. Approximately half of the total gas production is sold domestically. The Table below indicates both production and consumption of natural gas in Indonesia over the past decade.

Table 2: Natural Gas Production, and Consumption.

\begin{tabular}{|c|c|c|c|c|c|c|c|c|c|c|}
\hline & 2006 & 2007 & 2008 & 2009 & 2010 & 2011 & 2012 & 2013 & 2014 & 2015 \\
\hline $\begin{array}{c}\text { Production } \\
\text { (in million m2) }\end{array}$ & 74.3 & 71.5 & 73.7 & 76.9 & 85.7 & 81.5 & 77.1 & 72.1 & 73.4 & 75 \\
\hline $\begin{array}{c}\text { Consumption (in } \\
\text { million m2) }\end{array}$ & 36.6 & 34.1 & 39.1 & 41.5 & 43.4 & 42.1 & 42.2 & 36.5 & 38.4 & 39.7 \\
\hline
\end{tabular}

Source: Indonesia-Investments (2015).

As shown in the Table 2 - and in contrast to the national oil production - natural gas production in Indonesia remained stable, a record high in 2010 due to the start of production fields Tangguh (located in Papua) in the same year (has managed by BP Indonesia) which is an important project in the field of gas industry. After 2010, natural gas production has declined due to supply problems. Although many of smaller companies active in the natural gas sector, most of the domestic exploration and production is in the hands of six companies that have been mentioned, the only one owned by Indonesia (PT. Pertamina). When combined, CNOOC Ltd. of the People's Republic of China (PRC) and Pertamina contribute to more than half of Indonesia gas production.

PT. Perusahaan Gas Negara business activities in Indonesia, which began in 1859, make our companies has experience and excel in the natural gas business. We have built a network of transmission and distribution pipelines in Indonesia, which has reached more than $6,000 \mathrm{~km}$. We have introduced and started a new technology in the transportation of natural gas such as LNG and CNG. And now, we bring natural gas to more households in Indonesia. The business activity of this company starts from front to end business process which includes planning, construction, production development, distribution of processed gas, and transmission to industrial, commercial and household users.

\subsection{The Decree of Ministry of State Owned Enterprises}

According to (11) about financial health assessment of State Owned Enterprises, the growth of business should be supported by good infrastructure and evaluation system to measure the efficiency and level of competition among SEOs. This financial evaluation applies to all state-owned enterprises in the financial and non- 
financial industry. In non-financial industry, the companies are divided into infrastructure and non-infrastructure. This evaluation method consists of three aspects which are financial, operational, and administration. In a financial aspect, total weight score for infrastructure is 50 and non-infrastructure are 70 . There are eight indicators to measure the financial health such as return on investment, return on equity, cash ratio, current ratio, collections period, inventory turnover, total asset turnover, and total equity to the total asset. PT. BA and PT. PGN are state-owned enterprises which listed in non-infrastructure industries and comply with the list of assessments score shows in Table 3.

Table 3: List of Assessment Score.

\begin{tabular}{|l|c|}
\hline \multicolumn{1}{|c|}{ INDICATORS } & WEIGHT SCORE \\
\hline ROE & 20 \\
\hline ROI & 15 \\
\hline Cash Ratio & 5 \\
\hline Current Ratio & 5 \\
\hline Collection Period & 5 \\
\hline Inventory Turnover & 5 \\
\hline Total Asset Turnover & 5 \\
\hline Total Equity to Total Asset & 10 \\
\hline Total weight score & 70 \\
\hline
\end{tabular}

Source: The decree of Ministry of SOEs No. KEP 100/MBU/2002

\subsection{The Variables and Weight Score}

\section{a. Profitability Performance}

The profitability is the most common measure for company's financial performance. The equation for profitability measurement can be expressed as Return on Equity $(R O E)=\left(\frac{\text { Net Income }}{\text { Shareholderg'Equity }}\right) \times 100 \%$. Return on equity is an important ratio for investors to consider its profits. According to (12), ROE measures how efficiently a company can use the money from shareholders to generate profits and grow the company. Table 4 shows the assessment score of ROE. Return on investment is a profitability ratio that calculates the profits of an investment as a percentage of the original cost. The equation of ROI can be expressed as Return on Investment $(R O N)=\left(\frac{\text { EBIT+Depreciation }}{\text { Capital Employed }}\right) \times 100 \%$ and Table 5 shows the assessment score of ROI.

Table 4: List of ROE Assessment Score

\begin{tabular}{|c|c|}
\hline ROE (\%) & Score \\
\hline $15<\mathrm{ROE}$ & 20 \\
\hline $13<\mathrm{ROE}<=15$ & 18 \\
\hline $11<\mathrm{ROE}<=13$ & 16 \\
\hline $9,0<\mathrm{ROE}<=11$ & 14 \\
\hline $7,9<\mathrm{ROE}<=9$ & 12 \\
\hline $6,6<\mathrm{ROE}<=7,9$ & 10 \\
\hline $5,3<\mathrm{ROE}<=6,6$ & 8,5 \\
\hline $4,0<\mathrm{ROE}<=5,3$ & 7 \\
\hline $2,5<\mathrm{ROE}<=4$ & 5,5 \\
\hline $1,0<\mathrm{ROE}<=2,5$ & 4 \\
\hline $0<\mathrm{ROE}<=1$ & 2 \\
\hline ROE $<0$ & 0 \\
\hline
\end{tabular}

Source: The decree of Ministry of SOEs No. KEP 100/MBU/2002
Table 5: List of ROI Assessment Score.

\begin{tabular}{|c|c|}
\hline ROI $(\%)$ & Score \\
\hline $18<\mathrm{ROI}$ & 15 \\
\hline $15<\mathrm{ROI}<=18$ & 13,5 \\
\hline $13<\mathrm{ROI}<=15$ & 12 \\
\hline $12<\mathrm{ROI}<=13$ & 10,5 \\
\hline $10,5<\mathrm{ROI}<=12$ & 9 \\
\hline $9<\mathrm{ROI}<=10,5$ & 7,5 \\
\hline $7<\mathrm{ROI}<=9$ & 6 \\
\hline $5<\mathrm{ROI}<=7$ & 5 \\
\hline $3<\mathrm{ROI}<=5$ & 4 \\
\hline $1<\mathrm{ROI}<=3$ & 3 \\
\hline $0<\mathrm{ROI}<=1$ & 2 \\
\hline $\mathrm{ROI}<0$ & 1 \\
\hline
\end{tabular}

Source: The decree of Ministry of SOEs No. KEP 100/MBU/2002

\section{b. Liquidity Performance}

The equation of liquidity performance can be expressed as Cash Ratio $=\left(\frac{\text { Cash+Cash Equivalents }}{\text { Current Liabilities }}\right) \times 100 \%$. It measures the company ability to pay its short-term debt. If the company has cash ratio equal to one, it indicates that company has the same amount of cash and its debt. If the value of cash ratio is more than 1 , it indicates that company has more cash to pay its debt. However, if the value is less than 1 , it indicates that company has less cash to pay its debt. Table 6 shows the assessment score for cash ratio.

Table 6: List of Cash Ratio Assessment Score.

\begin{tabular}{|c|c|}
\hline Cash Ratio $=x(\%)$ & Score \\
\hline$x>=35$ & 5 \\
\hline $25<=x<35$ & 4 \\
\hline $15<=x<25$ & 3 \\
\hline $10<=x<15$ & 2 \\
\hline $5<=x<10$ & 1 \\
\hline $0<=x<5$ & 0 \\
\hline
\end{tabular}

\section{Source: The decree of Ministry of SOE No. KEP-100/MBU/2002}

In addition, the liquidity performance expressed in the formula as Current Ratio $=\left(\frac{\text { currentAsset }}{\text { current Liabilities }}\right) \times 100 \%$. It measures the company ability to repay its current liability with current asset. If the company has a current ratio below 1 , it indicates that company has a problem with its short-term debt. If the company has a too high current ratio, it indicates that company has a problem in managing their current asset. Table 7 shows the current ratio assessment score. 
Table 7: List of Current Ratio Assessment Score.

\begin{tabular}{|c|c|}
\hline Current Ratio $=\mathrm{x}(\%)$ & Score \\
\hline $125<=\mathrm{x}$ & 5 \\
\hline $110<=\mathrm{x}<125$ & 4 \\
\hline $100<=\mathrm{x}<110$ & 3 \\
\hline $95<=\mathrm{x}<100$ & 2 \\
\hline $90<=\mathrm{x}<95$ & 1 \\
\hline $\mathrm{x}<90$ & 0 \\
\hline
\end{tabular}

Source: The decree of Ministry of SOE No. KEP-100/MBU/2002

Furthermore, the liquidity performance also can be expressed as Collection Period $=\left(\frac{\text { Average Accounts Receivables }}{\text { Sales Revenue }}\right) \times 365$ days .

This ratio is an important indicator for the company to monitor their cash flow and the company ability to pay its debt in due date. Table 8 shows the assessment score for collection period.

Table 8: List of Collection Periods Assessment Score.

\begin{tabular}{|c|c|c|}
\hline Collection Periods $=\mathrm{x}$ (days) & Adjustment (days) & Score \\
\hline$x<=60$ & $30<x$ & 5 \\
\hline $60<x<=90$ & $30<x<=35$ & 4,5 \\
\hline $90<x<=120$ & $25<x<=30$ & 4 \\
\hline $120<x<=150$ & $20<x<=25$ & 3,5 \\
\hline $150<x<=180$ & $15<x<=20$ & 3 \\
\hline $180<x<=210$ & $10<x<=15$ & 2,4 \\
\hline $210<x<=240$ & $6<x<=10$ & 1,8 \\
\hline $240<x<=270$ & $3<x<=6$ & 1,2 \\
\hline $270<x<=300$ & $1<x<=3$ & 0,6 \\
\hline $300<x$ & $0<x<=1$ & 0 \\
\hline
\end{tabular}

\section{c. Activity Ratio}

This ratio measures how many time the inventory are being sold over a period. The activity ratio can be expressed in an equation as Inventory Turnover $=\left(\frac{\text { Cost of Goods sold }}{\text { Average Mnentory }}\right)$. Table 9 shows the assessment score for inventory turnover.

Table 9: List of Inventory Turnover Assessment Score.

\begin{tabular}{|c|c|c|}
\hline Inventory Turnover $=\mathrm{x}$ (days) & Adjustment (days) & Score \\
\hline $\mathrm{x}<=60$ & $30<\mathrm{x}$ & 5 \\
\hline $60<\mathrm{x}<=90$ & $30<\mathrm{x}<=35$ & 4,5 \\
\hline $90<\mathrm{x}<=120$ & $25<\mathrm{x}<=30$ & 4 \\
\hline $120<\mathrm{x}<=150$ & $20<\mathrm{x}<=25$ & 3,5 \\
\hline $150<\mathrm{x}<=180$ & $15<\mathrm{x}<=20$ & 3 \\
\hline $180<\mathrm{x}<=210$ & $10<\mathrm{x}<=15$ & 2,4 \\
\hline $210<\mathrm{x}<=240$ & $6<\mathrm{x}<=10$ & 1,8 \\
\hline $240<\mathrm{x}<=270$ & $3<\mathrm{x}<=6$ & 1,2 \\
\hline $270<\mathrm{x}<=300$ & $1<\mathrm{x}<=3$ & 0,6 \\
\hline $300<\mathrm{x}$ & $0<\mathrm{x}<=1$ & 0 \\
\hline
\end{tabular}

Source: The decree of Ministry of SOE No. KEP-100/MBU/2002

In addition, this ratio measures the efficiency of company ability to use its asset to generate sales. It can be expressed in the formula as Total Asset Turnover $=\left(\frac{\text { Revenue }}{\text { Capital Employed }}\right) \times 100 \%$. Table

10 shows the total asset turnover assessment score.

Table 10: List of Total Asset Turnover Assessment Score.

\begin{tabular}{|c|c|c|}
\hline TATO $=x(\%)$ & Adjustment $=\mathrm{x}(\%)$ & Score \\
\hline $120<x$ & $20<x$ & 5 \\
\hline $105<x<=120$ & $15<x<=20$ & 4,5 \\
\hline $90<x<=105$ & $10<x<=15$ & 4 \\
\hline $75<x<=90$ & $5<x<=10$ & 3,5 \\
\hline $60<x<=75$ & $0<x<=5$ & 3 \\
\hline $40<x<=60$ & $\mathrm{x}<=0$ & 2,5 \\
\hline $20<x<=40$ & $\mathrm{x}<0$ & 2 \\
\hline$x<=20$ & $x<0$ & 1,5 \\
\hline
\end{tabular}

Source: The decree of Ministry of SOE No. KEP-100/MBU/2002

\section{d. Solvency Ratio}

This ratio is similar to debt to equity ratio. If the company has less value, it indicates that company funding its asset inefficiently. In the other words, the company has very low net value for the investor. This ratio can be expressed in an equation as Total Equity to Total Asset $=\left(\frac{\text { Total Equity }}{\text { Total Asset }}\right) \times 100 \%$. Table 11 shows the solvency assessment score.

Table 11: List of Solvency Assessment Score.

\begin{tabular}{|c|c|}
\hline Total Equity to Total Asset $(\%)=\mathrm{x}$ & Score \\
\hline $\mathrm{x}<0$ & 0 \\
\hline $0<=\mathrm{x}<10$ & 4 \\
\hline $10<=\mathrm{x}<20$ & 6 \\
\hline $20<=\mathrm{x}<30$ & 7,25 \\
\hline $30<=\mathrm{x}<40$ & 10 \\
\hline $40<=\mathrm{x}<50$ & 9 \\
\hline $50<=\mathrm{x}<60$ & 8,5 \\
\hline $60<=\mathrm{x}<70$ & 8 \\
\hline $70<=\mathrm{x}<80$ & 7,5 \\
\hline $80<=\mathrm{x}<90$ & 7 \\
\hline $90<=\mathrm{x}<100$ & 6,5 \\
\hline
\end{tabular}

Source: The decree of Ministry of SOE No. KEP-100/MBU/2002

\section{Methodology}

The descriptive financial ratio was used to measure, describe and analyze the performance of two enterprises under Ministry of Energy and Mineral Resources. PT. Bukit Asam and PT. Perusahaan Gas Negara was selected because those companies are stateowned enterprises in non-financial services which qualified in this decree. Data were collected from Annual Report (audited) between 2011 and 2015. All variables used are ratio measurement scales were taken from the decree of Ministry of State Owned Enterprises No. KEP-100/MBU/2002 about financial health assessment of State Owned Enterprises. Additionally, this decree used to validate the performance of those enterprises whether in the healthy level or less healthy, or unhealthy position.

The level of financial assessment is divided into healthy (the highest level of financial literacy), less healthy (the middle level of financial literacy), and unhealthy (the lowest level of financial literacy). In highest category, there are three types of levels such as AAA (if the total score is more than 95 points), AA (if the total score is more than 80 and less than 95), An (if the total score is 
more than 65 and less than 80). In the middle category, there are three types of levels such as BBB (if it is more than 50 and less than 65), BB (if it is more than 40 and less than 50), and B (if it is more than 30 and less than 40). In the lowest category, there are three types of levels such as CCC (if it is more than 20 and less than 30), CC (if it is more than 10 and less than 20), and C (if it is less than 10).

The selection of the FRA method for this study is motivated the researchers' knowledge due to the limited literature review on coal mining and natural gas industry in Indonesia. In addition, financial ratios can be used to identify a company's specific strengths and weaknesses as well as providing detailed information about company profitability, liquidity, activity, and solvency (13) (14). Although accounting data in financial statements is subject to manipulation and financial statements are backward looking, they are the only detailed information available on the company's overall activities (15). Furthermore, they are the only source of information for evaluating management's potential to generate satisfactory returns in future (16)

\section{Result and Discussion}

\subsection{Profitability Analysis}

Figure 1(a) gives information about the return on investment and return on equity of PT. Bukit Asam between 2011 and 2015. Overalls, it shows that the percentage of ROI fluctuated, or the ROI ratios are $39.93 \%, 35.97 \%, 41.19 \%, 35.13 \%$, and $39.35 \%$ respectively. The minimum standard of the Decree is $18 \%$ for ROI, therefore all ROI ratios were above the standard. The percentage of ROE slightly decreased starting 2013 to 2015 (37.83\%, 34.21\%, $24.52 \%, 21.86 \%, 21.93 \%$, respectively). The minimum standard of the Decree is $15 \%$ for ROE, therefore all ROE ratios were above the standard. It can be concluded that PT. Bukit Asam has successfully maintained its profitability ratios.

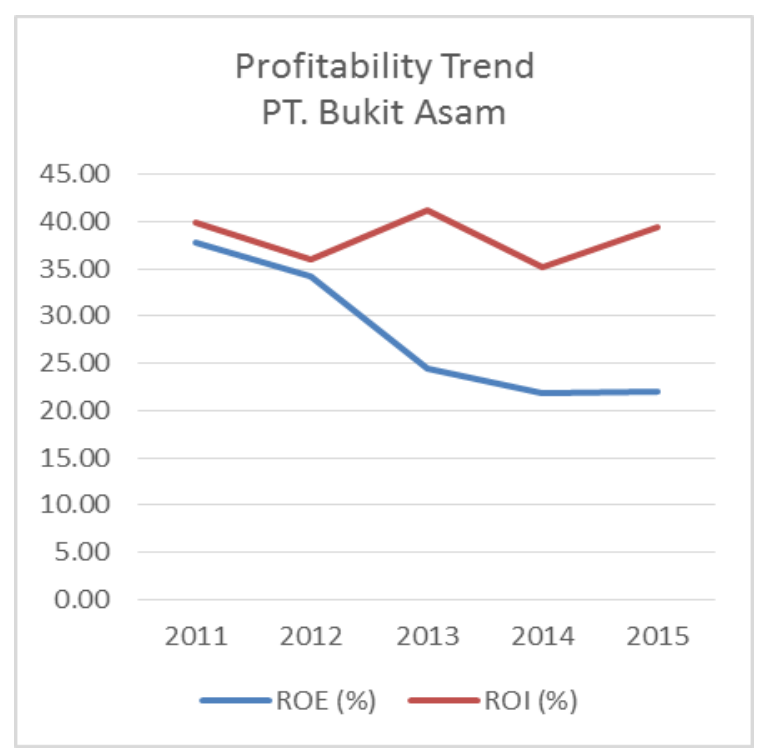

Fig. 1(a): Profitability Trend PT. Bukit Asam

Figure 1(b) above gives information about the return on investment and return on equity of PT. Perusahaan Gas Negara between 2011 and 2015. Overalls, it shows that the percentage of ROI fluctuated, $(16.57 \%, 14.59 \%, 21.75 \%, 24.14 \%$, and $25.31 \%$, respectively). There were ROI ratios of the years 2012 and 2013 that did not meet the minimum standard of $18 \%$. The percentage of ROE decreased significantly $(18.11 \%, 18.20 \%, 16.89 \%, 7.85 \%$, and $7.41 \%$, respectively). For the last two years, the ROE ratios were not met the minimum standard of $15 \%$. There was a dramatic increase in ROI percentage, while ROE percentage decreased sharply.

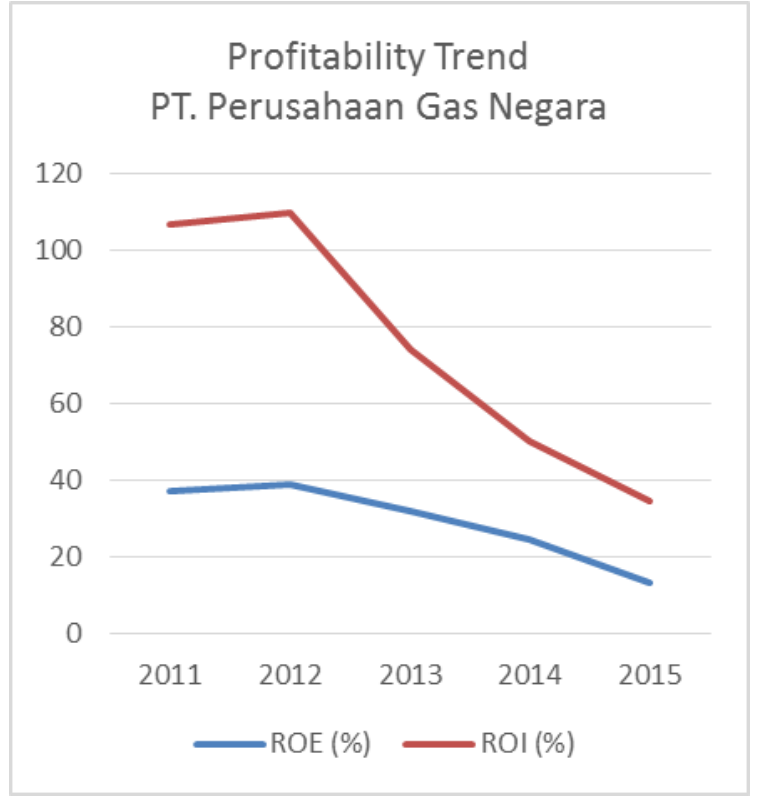

Fig. 1(b): Profitability Trend PT. Perusahaan Gas Negara

\subsection{Liquidity Analysis}

Figure 2 (a) gives information about the liquidity performance in PT. Bukit Asam between 2011 and 2015. Overalls, there was a significant decrease in the percentage of cash ratio and current ratio. The percentage of current ratio increased slightly from $461.85 \%$ in 2011 to $492.37 \%$ in 2012 . It shows the good liquidity. However, it decreased to $154.35 \%$ in 2011 which are only onethird of the year 2011. It means that every Rp. 1,- in current liability is secured by Rp. 1.54 of current assets, meaning that the company is still liquid.

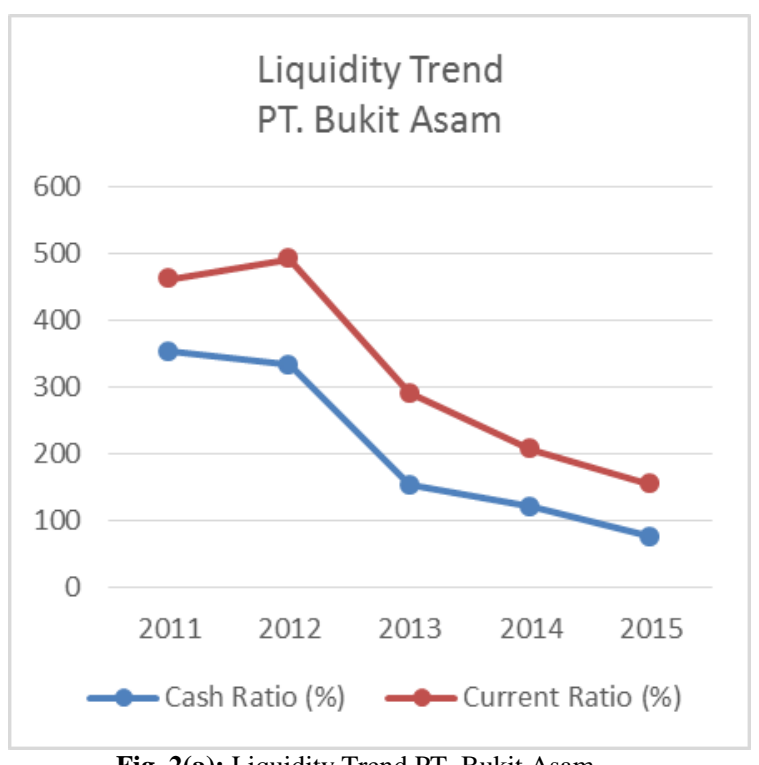

There was a significant decrease in the percentage of cash ratio from 354.01 in 2011 to $75.96 \%$ in 2015.

Figure 2(b) gives information about the percentage of cash and current ratio in PT. Perusahaan Gas Negara between 2011 and 2015. Overalls, there was a slight decrease in the percentage. The highest was current ratio and the lowest was cash ratio. The percentage of current ratio was very liquid from $550.22 \%$ in 2011 to 419.63 in 2012. It shows that PT. Perusahaan Gas Negara was conservative in managing their equity. However, it decreased to 210.58 and then increased to 258.13 in 2015 . It was accordance 
with banking standards, $200 \%$ which means that Rp. 1,- of current liability is secured by Rp. 2,- of current assets. The percentage of cash ratio decreased slightly from $428.07 \%$ in 2011 to $179.85 \%$ in 2015. In liquidity ratio, PT. Bukit Asam and PT. Perusahaan Gas Negara are considered successful in managing their working capital more efficiently. Cash management has also become much more efficient with decreasing cash ratio within a safe limit in the last five years, meaning that PT. Bukit Asam and PT. Perusahaan Gas Negara did not let the cash idle. They do not have any shortterm financial problem.

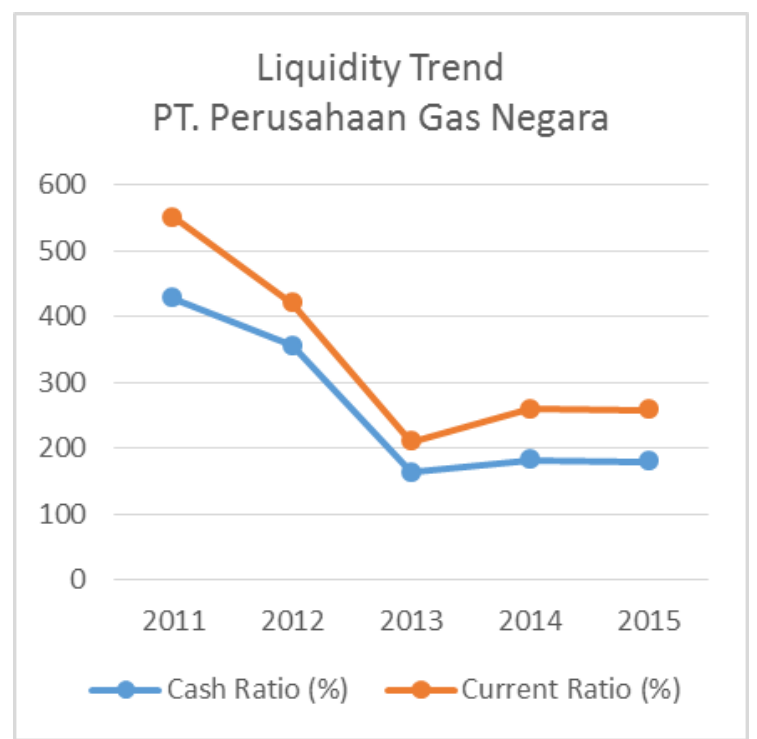

Fig. 2(b): Liquidity Trend PT. Perusahaan Gas Negara

\subsection{Activity Analysis}

Figure 3(a) gives information about inventory turnover (ITO), total assets turnover (TATO), and collection day's period (CP) for PT. Bukit Asam between 2011 and 2015. Overalls there were fluctuated in the percentage of their ratios. The highest ratio was total assets turnover and the lowest ratio was inventory turnover. In total assets turnover, there was a slight increase from $105.95 \%$ in 2011 to $129.07 \%$ in 2013 and it decreased slightly to $123.79 \%$ in 2015. The number of collection periods increased slightly from 41 days in 2011 to 46 days in 2013 , and then it decreased to 42 days in 2015. It is suggested to decrease the number of days to be below 30 . The percentage of inventory turnover increased steeply from $22.24 \%$ in 2011 to $29.37 \%$ in 2013 and a further increased to $32.77 \%$ in 2015 .

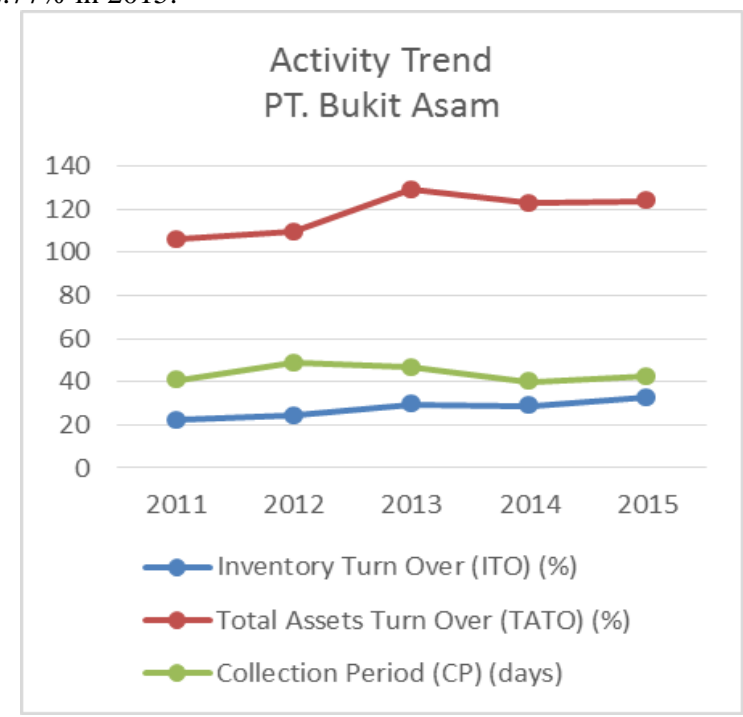

Fig. 3(a): Activity Trend PT. Bukit Asam
Figure 3(b) shows the percentage of inventory turnover, total assets turnover, and collection day's period for PT. Perusahaan Gas Negara between 2011 and 2015. Overalls there were a sharp decrease in the percentage of total assets turnover and fluctuated in the percentage of inventory turnover and collection period. In 2011, the percentage of total assets turnover decreased from $137.18 \%$ to $69.28 \%$ in 2015 . The number of collection period decreased from 36 days in 2011 to 31 days in 2013, and then it increased again to 34 days in 2015 . The percentage of inventory turnover increased slightly from $0.32 \%$ in 2011 to $7.02 \%$ in 2014 , and then it decreased to $5.17 \%$ in 2015 . In the activity ratio, the high performance of ROE and ROI are supported by highly productive activity ratios. PT. Bukit Asam has a good achievement in activity ratio, however PT. Perusahaan Gas Negara has a lower performance even though the value rose in the last five years. It suggested improving their inventory management and the collection period of 5 years should be less than 40 days, it is recommended to change it to 30 days.

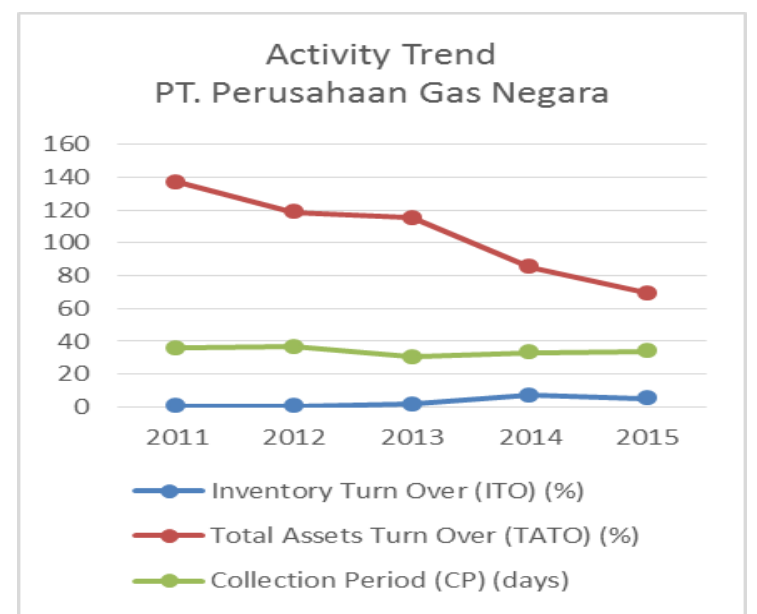

Fig. 3(b): Activity Trend PT. Perusahaan Gas Negara

\subsection{Solvency Analysis}

Figure 4(a) shows the percentage of total equity to the total asset in PT. Bukit Asam between 2011 and 2015. Overalls, there was a slight decrease in the percentage of solvency ratio. In 2011, the percentage was $70.91 \%$ and then it decreased to $54.98 \%$ in 2015 . It means that half of the total assets $(54.98 \%)$ were financed by owner's equity or in other words, the amount of debt is smaller than the total owner's equity. In the long term, PT. Bukit Asam does not have financial problems which reflected from the TETA. Although it declined, but it is still within safe limits. So, PT. Bukit Asam achieved the status of liquid and solvent.

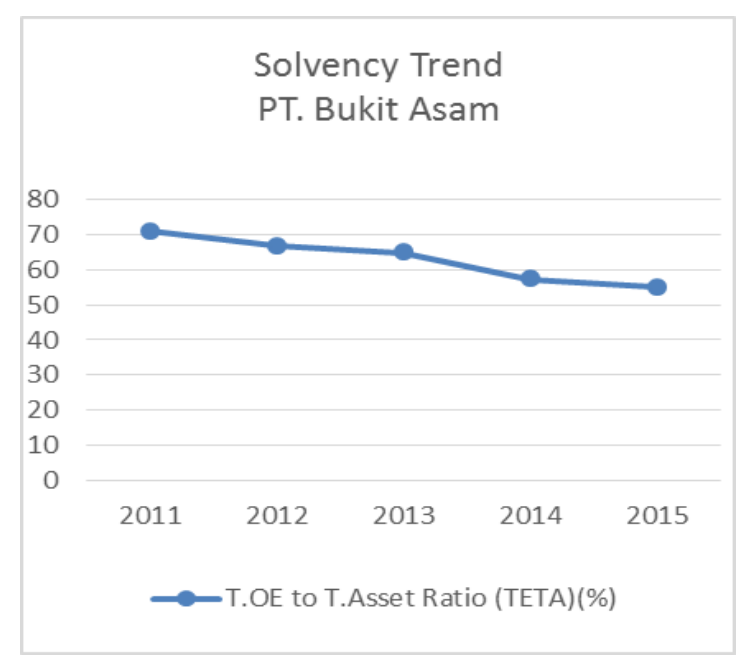

Fig. 4(a): Solvency Trend PT. Bukit Asam 
Figure 4(b) shows the percentage of solvency ratio in PT. Perusahaan Gas Negara between 2011 and 2015. Overalls, there was a slight decrease in the percentage of total equity to the total asset. The percentage increased from $55.27 \%$ in 2011 to $63.01 \%$ in 2013 , then it decreased to $46.54 \%$ in 2015 . In the long term, PT. Perusahaan Gas Negara did not have a financial relationship because its value was still above $50 \%$. However, the lowest percentage or below 50\% was in 2015. In other words, half of its total asset was financed by its liability. The total of debt is higher $3.46 \%$ from total equity.

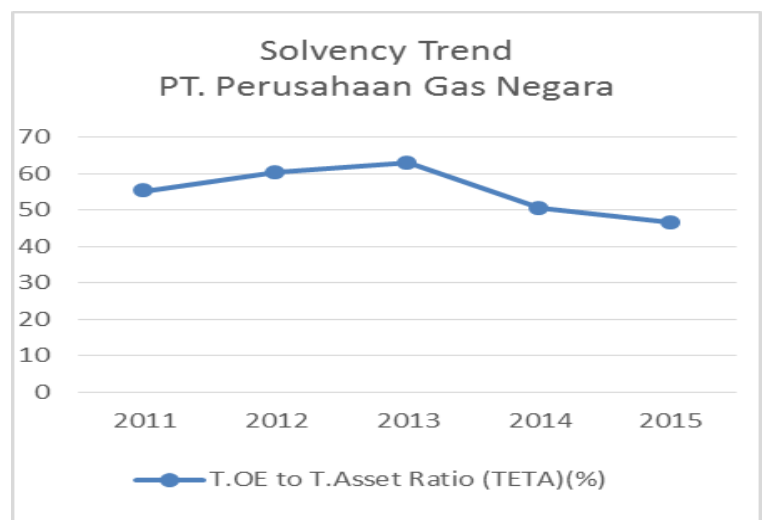

\subsection{Validation Testing}

To examine the level of financial assessment for two enterprises under Ministry of Energy and Mineral Resources (EMR) whether, in healthy or less healthy or unhealthy position from 2011-2015, the decree of Ministry of State Owned Enterprises No. KEP$100 / \mathrm{MBU} / 2002$ is employed to test the validation. Overall, based on table 12 and 13, there was a slight increase in the total score. It increased slightly from 65.50 in 2011 to 66.00 in 2012 and a further increased to 68.00 in 2013. Next, the total score converted to the total weight by the calculation formula $\left(\frac{\text { Total gcore }}{\text { Weight }}\right) \times 100$. The highest weight score was 97.14 in 2015 with level AAA or consider as healthy financial condition. The lowest weight score was 93.57 in 2011 with level AA or consider as healthy financial condition.

Fig. 4(b): Solvency Trend PT. Perusahaan Gas Negara

Table 12: Test Results for PT. Bukit Asam.

\begin{tabular}{|c|c|c|c|c|c|c|c|c|c|c|}
\hline \multirow[b]{2}{*}{ INDICATORS } & \multicolumn{2}{|c|}{2015} & \multicolumn{2}{|c|}{2014} & \multicolumn{2}{|c|}{2013} & \multicolumn{2}{|c|}{2012} & \multicolumn{2}{|c|}{2011} \\
\hline & RATIO & SCORE & RATIO & SCORE & RATIO & SCORE & RATIO & SCORE & RATIO & SCORE \\
\hline ROE & 21.93 & 20 & 21.86 & 20 & 24.52 & 20 & 34.21 & 20 & 37.83 & 20 \\
\hline ROI & 39.35 & 15 & 35.13 & 15 & 41.19 & 15 & 35.97 & 15 & 39.93 & 15 \\
\hline CASH RATIO & 75.96 & 5 & 121.08 & 5 & 154.03 & 5 & 334.17 & 5 & 354.01 & 5 \\
\hline $\begin{array}{l}\text { CURRENT } \\
\text { RATIO }\end{array}$ & 154.35 & 5 & 207.12 & 5 & 290.90 & 5 & 492.37 & 5 & 461.85 & 5 \\
\hline $\begin{array}{l}\text { COLLECTION } \\
\text { PERIOD }\end{array}$ & 42.41 & 5 & 40.17 & 5 & 46.49 & 5 & 48.66 & 5 & 40.71 & 5 \\
\hline $\begin{array}{l}\text { INVENTORY } \\
\text { TURNOVER }\end{array}$ & 32.77 & 4.5 & 28.84 & 4 & 29.37 & 4 & 24.11 & 3.5 & 22.24 & 3.5 \\
\hline TATO & 123.79 & 5 & 122.74 & 5 & 129.07 & 5 & 109.62 & 4.5 & 105.95 & 4.5 \\
\hline $\begin{array}{ll}\text { TOTAL } & \\
\text { EQUITY } \\
\text { TOTAL } \\
\text { ASSET } & \\
\end{array}$ & 54.98 & 8.50 & 57.37 & 8.50 & 64.77 & 8 & 66.82 & 8 & 70.91 & 8 \\
\hline & Total & 68.00 & Total & 67.50 & Total & 67.00 & Total & 66.00 & Total & 65.50 \\
\hline
\end{tabular}

Table 13: Summary Results for PT. Bukit Asam.

\begin{tabular}{|c|c|c|c|c|c|c|}
\hline Years & $\begin{array}{c}\text { Total } \\
\text { Score }\end{array}$ & Weight & $\begin{array}{c}\text { Total } \\
\text { Weight }\end{array}$ & Value & Level & Category \\
\hline 2015 & 68.00 & 70 & 97.14 & $80<\mathrm{TS}<=95$ & AAA & Healthy \\
\hline 2014 & 67.50 & 70 & 96.43 & $80<\mathrm{TS}<=95$ & AAA & Healthy \\
\hline 2013 & 67.00 & 70 & 95.71 & TS $>95$ & AAA & Healthy \\
\hline 2012 & 66.00 & 70 & 94.29 & $80<\mathrm{TS}<=95$ & AA & Healthy \\
\hline 2011 & 65.50 & 70 & 93.57 & $80<\mathrm{TS}<=95$ & AA & Healthy \\
\hline
\end{tabular}

Table 14: Test Results for PT. Perusahaan Gas Negara.

\begin{tabular}{|c|c|c|c|c|c|c|c|c|c|c|}
\hline \multirow[b]{2}{*}{ INDICATORS } & \multicolumn{2}{|c|}{2015} & \multicolumn{2}{|c|}{2014} & \multicolumn{2}{|c|}{2013} & \multicolumn{2}{|c|}{2012} & \multicolumn{2}{|c|}{2011} \\
\hline & RATIO & SCORE & RATIO & SCORE & RATIO & SCORE & RATIO & SCORE & RATIO & SCORE \\
\hline ROE & 7.41 & 10 & 7.85 & 10 & 16.89 & 20 & 18.20 & 20 & 18.11 & 20 \\
\hline ROI & 25.31 & 15 & 24.14 & 15 & 21.75 & 15 & 14.59 & 12 & 16.57 & 13.5 \\
\hline CASH RATIO & 39.97 & 5 & 29.28 & 4 & 29.82 & 4 & 32.47 & 4 & 27.38 & 4 \\
\hline $\begin{array}{l}\text { CURRENT } \\
\text { RATIO }\end{array}$ & 167.67 & 5 & 149.09 & 5 & 145.50 & 5 & 157.70 & 5 & 139.09 & 5 \\
\hline $\begin{array}{l}\text { COLLECTION } \\
\text { PERIOD }\end{array}$ & 22.25 & 3.5 & 17.92 & 3.0 & 20.50 & 3.5 & 19.96 & 3.0 & 19.32 & 3.0 \\
\hline $\begin{array}{l}\text { INVENTORY } \\
\text { TURNOVER }\end{array}$ & 39.09 & 5.0 & 37.03 & 5.0 & 46.93 & 5.0 & 46.39 & 5.0 & 42.43 & 5.0 \\
\hline TATO & 118.19 & 4.5 & 171.86 & 5 & 175.53 & 5 & 215.51 & 5 & 247.48 & 5 \\
\hline $\begin{array}{l}\text { TOTAL } \\
\text { EQUITY TO } \\
\text { TOTAL } \\
\text { ASSET }\end{array}$ & 42.78 & 9.00 & 37.11 & 10 & 36.69 & 10 & 37.16 & 10 & 38.03 & 10 \\
\hline & Total & 57.00 & Total & 57.00 & Total & 67.50 & Total & 64.00 & Total & 65.50 \\
\hline
\end{tabular}


Table 15: Summary Results for PT. Perusahaan Gas Negara.

\begin{tabular}{|c|c|c|c|c|c|c|}
\hline Years & $\begin{array}{c}\text { Total } \\
\text { Score }\end{array}$ & Weight & $\begin{array}{c}\text { Total } \\
\text { Weight }\end{array}$ & Value & Level & Category \\
\hline 2015 & 60.70 & 70 & 86.71 & $80<\mathrm{TS}<=95$ & AA & Healthy \\
\hline 2014 & 63.30 & 70 & 90.43 & $80<\mathrm{TS}<=95$ & AA & Healthy \\
\hline 2013 & 62.60 & 70 & 89.43 & TS $>95$ & AA & Healthy \\
\hline 2012 & 62.50 & 70 & 89.29 & $80<\mathrm{TS}<=95$ & AA & Healthy \\
\hline 2011 & 63.50 & 70 & 90.71 & $80<\mathrm{TS}<=95$ & AA & Healthy \\
\hline
\end{tabular}

As seen in table 14 and 15 , there was a slight decrease in the total score between 2011 and 2015. It decreased slightly from 63.50 in 2011 to 62.50 in 2012 and it remained table until 2013. Then, it increased to 63.30 in 2014 and it decreased again to 60.70 in 2015 . Next, the total score converted to the total weight by the calculation formula $\left(\frac{\text { Total score }}{\text { Weight }}\right) \times 100$. Between 2011 and 2015, the company gets level AA which considers as healthy in financial condition.

\section{Conclusion}

The study shows the financial performance of coal mining and natural gas industry between 2010 and 2015. Based on the decree of Ministry of State Owned Enterprises No. KEP-100/MBU/2002 about financial health assessment of State Owned Enterprises, the study concerns about four ratio measurement that include liquidity, solvency, profitability and activity ratio. The outcome shows that PT. Bukit Asam and PT. Perusahaan Gas Negara have good financial performance. The highest level of health financial was PT. Bukit Asam with three level AAA from 2013 to 2015 and the financial performance for the other years was AA. The company is encouraged to maintain its profitability in the future by increasing their activity ratios, both inventory turnover, and total asset turnover. In the situation of decreasing coal price currently, the company's strategy may be either increase the sales volume or cost reduction policies or both ways. On the other hand, PT. Perusahaan Gas Negara get level AA for five years' period. It is expected that the company may achieve the highest level of AAA in the future years. It is recommended that the company increase its sales volume by expanding its market share by distributing gas throughout the country. While internally the company should manage the cost efficiently. In order to survive or going concern, the company should certain of its security of the supply of gas, as its merchandise inventory. It is recommended that the company make a decision on merger or acquisition with a gas industry. This result implied that coal mining and natural gas sector industry can increase their market share, even though the industry faces major challenges. This study has added the knowledge in the financial literature. It also gives a strong insight for managers in oil and gas industry about the financial performance. Therefore, the managers can make a better decision with the purpose to increase the market share.

\section{References}

[1] Petroleum B. Statistical Review of World Energy2015. Available from: http://www.bp.com/en/global/corporate/energyeconomics/statistical-review-of-world-energy.html.

[2] Investments I. Natural Gas in Indonesia2016. Available from: https://www.indonesiainvestments.com/business/commodities/natural-gas/item 184 .

[3] Neraca HE. Menperin: industri penunjang migas terbelit masalah. Available from: http://www.kemenperin.go.id/artikel/3753/Menperin:-IndustriPenunjang-Migas-Terbelit-Masalah.
[4] Edmister RO. An Empirical Test of Financial Ratio Analysis for Small Business Failure Prediction. Journal of Financial and Quantitative Analysis. 1972;7(2):1477-93.

[5] SUEYOSHI T. Financial Ratio Analysis of the Electric Power Industry. Asia-Pacific Journal of Operational Research. 2005;22(3):349-76.

[6] Investments I. Indonesia's Coal Production and Export2015. Available from: http://www.indonesiainvestments.com/business/commodities/coal/item236.

[7] Julzarika A, Kuncoro, T. S. Utilization of Sar and Earth Gravity Data for Sub Bituminous Coal Detection. International Journal of Remote Sensing and Earth Sciences. 2014;11(2):143-52.

[8] Srivastava AK. Coal Mining Industry in India1998.

[9] Hamilton MS. Mining Environmental Policy: Comparing Indonesia and the US2005.

[10] Ardiansyah F. The Energy Challenge2011. Available from: http://www.insideindonesia.org/the-energy-challenge-3.

[11] BUMN K. Salinan Keputusan Menteri Badan Usaha Milik Negara Nomor: KEP-100/MBU/2002. 2002.

[12] Anthony RN, Reece, J.S., Hertenstein, J.H. Accounting: Text and Cases. 13th ed. Chicago: Irwin; 2011.

[13] Hempel G, Simonson, D., Coleman, A. Bank Management: Text and Cases. 4th ed: John Wiley \& Sons, Inc.; 1994.

[14] Dietrich J. Financial Services and Financial Institutions: Value Creation in Theory and Practice. Upper Saddle River, NJ: Prentice Hall; 1996.

[15] Sinkey J. Commercial Bank Financial Management: In the Financial-Services Industry. 6th, editor. Upper Saddle River, NJ: Prentice Hall; 2002.

[16] Kumbirai M, Webb, R. A Financial Ratio Analysis of Commercial Bank Performance in South Africa. African Review of Economics and Finance. 2010;2(1):30-53. 